\title{
Bacteriophages against Antibiotic Resistant Salmonella Bacteria for the Possible Prevention and Treatment of Birds and Clean Up of their Water Habitats
}

International Center for Environmental Research (ICFER), Tbilisi, Georgia

\begin{abstract}
In veterinary practice for the prevention of salmonella infections has been used vaccination and partial antibacterial preparations (antibiotics, antimicrobial chemical therapy preparations), which had been used for the therapy of ill animals. During decades, the unsustainable use of antibiotics and antimicrobial chemical therapy preparations in veterinary practice caused the selection of pathogenic residential form of microbes, which resulted significant reduction of therapeutic effect of preparations. During the use of antibiotics for the prevention and treatment of salmonella disease among animals is not efficient. In most cases the animals are becoming caries of diseases and are still staying as a dangerous source for epidemic. The part of the salmonella bacteria which cause salmonella among animals: S. typhi-murium; S. Dublin; S. enteritidis.; S. choleraesuis; $S$ antum; as well as S. paratyphi $A$ and $S$. paratyphi $B$, do not cause illness among animals, but are dangerous for humans, because they cause salmonella diseases among people. Therefore, it becomes more important to create safe preparation against salmonella diseases as bacteriophages preparations. Their practical usefulness is defined: by its highly specific action oriented effect and lack of correlation towards other anti-microbe preparations of bacteria. After the prevention and treatment and with specific bacteriophages in comparison with other anti-microbe and chemical preparations we can significantly reduce the quantity of bacteria carriers. The purpose of our project (the World Bank's Georgian Agriculture Development Program's Project - CGS 03-70) was to demonstrate environmentally friendly, sustainable and efficient veterinary technology against antibiotic resistant microbes: Salmonella abortus ovi, $S$. abortus equi; $S$ gallinarum; S. pullozum; S. typhimurium; S. dublin; Salmonella Enteritidis; S. cholerae suis; S antum; S. Hajnia abvei Moller, and by means of selection of highly efficient and clean bacteriophages the creation of preventive- treating veterinary preparations for its further practical use.
\end{abstract}

Keywords: Salmonella abortus ovi; S. abortus equi; S. gallinarum; S. pullozum; S. typhimurium; S. dublin; Salmonella enteritidis

\section{Introduction}

Since the end of the $18^{\text {th }}$ century Europe studied about animals' salmonellosis, wide group of pathogenic microbes of S. suipertifer (later called as S. choleraesuis) separated from the dead body of pig by Salimn Smith in 1885. As a disease of poultry, it has been studied since 1899. However wild bird surveys were prioritised as disease was considered as sources for human infections [1]. In 1934 International Microbiological Society called the group of microbes Salmonellas, and the infectious disease caused by them -salmonellosis.

Antibiotics and antimicrobial chemical therapy preparations were widely used in veterinary practice for the prevention of salmonella infections since 1930-th in Georgia [2]. However unsustainable use of antibiotics caused creation of resistant, therapeutic effect reduced form of microbes.

In 1915 English bacteriologist Frederick William Twort isolated viruses, which can destroy bacteria. Later in 1917 French-Canadian National D'Herele find 'a virus parasitic to bacteria' and called it bacteriophage that in Greek means bacteria eater. At the same time, Georgian microbiologist George Eliava was observing the same phenomenon [2].

Salmonella is a genus of bacteria that are a major cause of foodborne illness throughout the world. The bacteria are generally transmitted to humans through consumption of contaminated food of animal origin, mainly meat, poultry, eggs and milk [3].

Numerous experimental studies have been conducted from different research groups showing the effectiveness of bacteriophages on Campylobacter and Salmonella [3]. Phage therapy became promising; however, development and application of a commercial product would have need much extensive research.

Salmonella species are widespread in the environment, and occur in cattle, pigs, and birds, including poultry and free-living birds. In this study, we determined the occurrence of Salmonella in different wild bird species in Poland, focusing on five Salmonellaserovars monitored in poultry by the European Union: Salmonellaserovars Enteritidis, Typhimurium, Infantis, Virchow, and Hadar [4].

The purpose of our manuscript is to present outcomes of WB Georgian Agriculture Development Program's Project - CGS 03-70 "Demonstration and application of achievement of environmentally friendly and efficient technology on the use of treatment-preventive

Grigol Abramia, Director and CEO, International Center for Environmental Research (ICFER), Tbilisi, 0179, Georgia, Tel: 995-599-246-287 E-mail:gia_abramia@hotmail.com

October 13, 2016; $\quad$ October 21, 2016;

October 26 2016

Abramia G, Golijashvili A, Rigvava S, Natidze M, Japarashvili N, et al (2016) Bacteriophages against Antibiotic Resistant Salmonella Bacteria for the Possible Prevention and Treatment of Birds and Clean Up of their Water Habitats. J Vet Sci Technol 7: 395. doi: 10.4172/2157-7579.1000395

(c) 2016 Abramia G, et al. This is an open-access article distributed under the terms of the Creative Commons Attribution License, which permits unrestricted use, distribution, and reproduction in any medium, provided the original author and source are credited. 
Citation: Abramia G, Golijashvili A, Rigvava S, Natidze M, Japarashvili N, et al. (2016) Bacteriophages against Antibiotic Resistant Salmonella Bacteria for the Possible Prevention and Treatment of Birds and Clean Up of their Water Habitats. J Vet Sci Technol 7: 395. doi: 10.4172/21577579.1000395

Page 2 of 6

veterinary biopreparation of bacteriophages against antibiotic resistant salmonella infections in poultry" [5].

The project aimed to demonstrate environmentally friendly, less harmful, sustainable veterinary technology against antibiotic resistant microbes of salmonella: Salmonella abortus ovi, S. abortus equi; $S$. gallinarum; S. pullozum; S. typhimurium; S dublin; S. enteritis's; s. choleraesuis; S antum; S. hajnia abvei Moller; and by means of selection of specific bacteriophages the creation of preventive- treating veterinary preparations for its further practical use. The project was implemented in 2 poultry farms of Georgia: Dedoplistskaro and Krtsanisi, Georgia.

PIT planned project cycles: planning, preparation period, implementation, data analyses and reporting. Has been audited existing documents and interviewed local veterinarians and identified: total amount of chicken; illness and relevant problems; environmental situation at the farm; indicators of fall. The study covered provided preventive-treatment measures (vaccination, antibiotics, chemical therapy) at the farm during past year period assed the efficiency and analyzed the results [6].

As well as the duration and periods of infectious diseases in different age groups, their occurrence their quality and quantity indicators. Has been separated and selected the strains of infection creating bacteria of salmonella and other bacteria and study their morpho-cultural, biochemical, serological characteristics and their vulnerability towards antibiotics and phages [7]; Separated and selected wide range and high life activity phages, influencing on salmonella strains produced at farm (farms); Improvement of the quality, inspection and methodology of their processing.

\section{Methodology}

The research was conducted in Krtsanisi and Patardzleuli poultry farms in Georgia in four stages: planning, preparatory period, implementation and data analyses and reporting. Stage one has undertaken seven steps: identification of total amount of birds; study of diseases and other problems; study environmental condition of farm; sanitary -chemical analyses of water; (Figure 1) indicators of falling; provided preventive measures; studied diseases in different ages; analyses and processing of compiled information, planning.

The implementation of stage 2 was followed by: 2-month preparatory period; identifying total amount of chicken; study of the dynamics of diseases by years; has been provided environmental impact assessment of the farm and its adjacent territory; studied the reasons of illness and the dynamics of their fall during the years in different age groups (Figure 2).

Bacterial research has been provided on 6-day egg laying chickens' faecal excreta and pathological organs of fallen chicken (heart, liver, spleen, and rectum) also ready-made food (Figure 3).

Selected material was inseminated on sugar broth and organs were processed by disinfected solution, was made cutting and the material was taken from internal layer. Has been provided research in 3 methods: microbiological, microscopic, and serological.

Has been used selected elective- selective soils, as well as disinfection diagnostic soils: Endo agar, MacConkey, Enterococci and Pseudomonas' agars. Has been studied bacterioscopy of individual isolates and used Gram's method. All separated isolates were inseminated in $0.3 \%$ semifluid agar. We applied for tingling movement study and hanging drop method for identification of Salmonella gallenarum-pullorum. Has been provided serodiagnostics with Salmonella ABCDE adsorbed serum and Shigella polyvalent serum. Selected pathogenic strains were tested on 12 antibiotics for vulnerability. Resistant strains were undergone phage diagnostics with intesi and pio bacteriophages. Has been conducted bacteriological research on sensitivity on antibiotics, and phage sensitivity among 1-10 days old chickens (Figure 4).

Resistant to phages strains were inseminated into the water from Patardzleuli poultry farm. Has been provided bacteriophage research of sewage water in Krtsanisi poultry farm (Figure 5). Were separated $E$. coli and Salmonella phages. Has been conducted several passages (for the raising of activation) separated phages were bottled and submitted to the Patardzleuli poultry farm.

Has been provided tests for the identification of prophylaxis and influence of intestine-bacteriophage on bird's organism. Experiments were undertaken in Krtsanisi and Patardzleuli poultry farms. For the purpose of identification of intestinal vindication of intestinebacteriophage we have preliminary identified $\mathrm{pH}$ in birds' gizzard, stomach and intestines. $\mathrm{PH} 5.0$ and $\mathrm{pH} 8.0$ are not influencing on phage's operation during 24 hours. Studies of $\mathrm{pH}$ in birds' food digestion system identified that the amount of $\mathrm{pH}$ from 10 day and 4-week-old birds fluctuates from 8 until 5.5. Stomach 3.0-4.0 and intestine 6.0.

\section{Results and Suggestions}

In accordance with the decision (Protocol N 16 28.05.03) of Zootechnical Veterinarian University of Georgia the use of poli valent intestine-bacteriophage, as environmentally clean preparation without side events was recommended for the treatment of birds' salmonella bacterial diseases.

\section{Main results of the project were:}

- Intestibacteriophage preparation of veterinary phages against infections caused by antibiotic resistant salmonella strains;

- Study on efficiency in vitro in vino of veterinary preventivetreatment bacteriophages preparations;

- Improved method of creating veterinary, specific high efficient, cleansing preventive- treatment phages preparations of salmonella for the purpose of its further use;

- Georgian Veterinary Preparation Scientific Control Center (16.08. 2004);

- Instruction approved by State Veterinary Department of Georgia on preventive- treatment phages preparations of salmonella; (30.08. 2004);

- Water bacterial treatment technology by bacteriophages.

- Educational documentary film- Bacteriophages, Historical Survey 1923-2004

Wild birds may become infected through carnivorous behaviour, or environmental contamination. Wild birds that are carnivorous or omnivorous are therefore most commonly infected, as they are consuming food that is contaminated such as intestine, consuming feed that is on the ground, or feeding or living in contaminated water.

Wild birds are known to be reservoirs for Salmonella spp. [8]. Previous studies have found that Salmonella is present sporadically in the intestinal flora of wild birds [9].

Ramsar Convention on Wetlands, 1971 sites all over the world are important habitats and wintery for migratory birds. Consequently, 


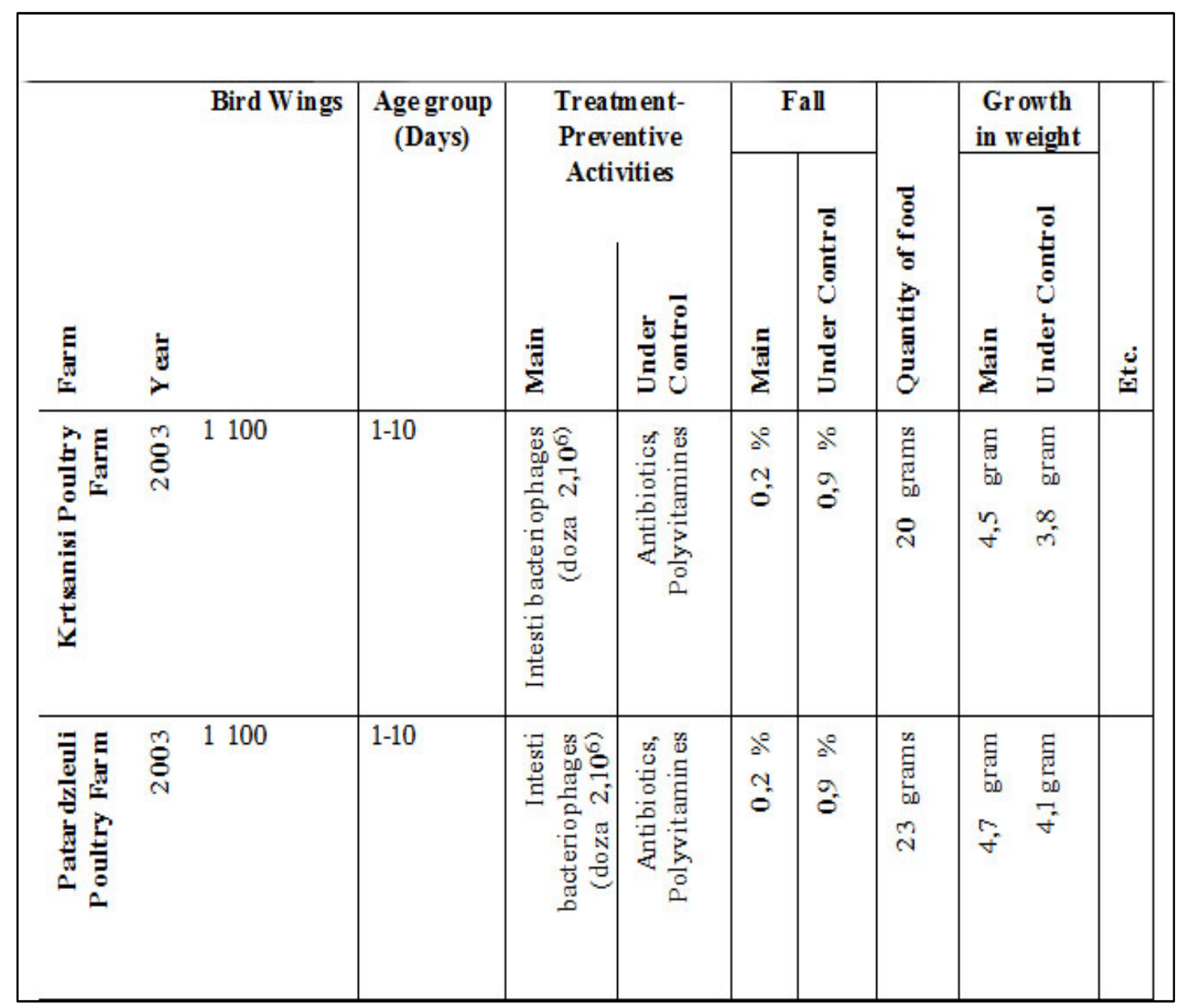

Quantity, age groups, treatment preventive activities, fall and grows in weight.

\begin{tabular}{|lll|l|}
\hline Ne & Indic ator & Quantity & MAC \\
1. & Transparency (sm.) & 25 & $>30$ \\
2. & Color (grade) & 10 & 5 \\
3. & Smell (points) & 0 & 2 \\
4. & Total hardness (mg/l) & 44 & $7-10$ \\
5. & Calcium (mg/l) & 420,84 & $40-120$ \\
6. & Magnum $(\mathrm{mg} / \mathrm{l})$ & 279,68 & 15 \\
7. & Ammonia $(\mathrm{mg} /)$ & 2,5 & 2 \\
8. & Nitrites $(\mathrm{mg} / \mathrm{l})$ & 0,04 & 0,1 \\
9. & Nitrates $(\mathrm{mg} / \mathrm{l})$ & 0 & 45 \\
10. & Sulphates $(\mathrm{mg} / \mathrm{l})$ & 2500 & 500 \\
11. & Chlorides $(\mathrm{mg} / \mathrm{l})$ & 1900 & 350 \\
12. & Mineralization $(\mathrm{mg} / \mathrm{l}))$ & 8400 & 1000 \\
& & \\
\hline
\end{tabular}


Citation: Abramia G, Golijashvili A, Rigvava S, Natidze M, Japarashvili N, et al. (2016) Bacteriophages against Antibiotic Resistant Salmonella Bacteria for the Possible Prevention and Treatment of Birds and Clean Up of their Water Habitats. J Vet Sci Technol 7: 395. doi: 10.4172/21577579.1000395

\begin{tabular}{|c|c|c|c|c|c|c|c|c|c|c|c|c|c|c|c|c|}
\hline & & & & & & & & & & & & & & & $\begin{array}{l}\text { Bac } \\
\text { pha }\end{array}$ & $\begin{array}{l}\text { erio } \\
\text { es }\end{array}$ \\
\hline 1 & 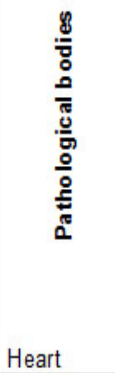 & 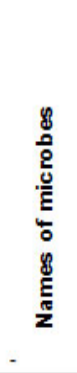 & $\begin{array}{l}\frac{n}{40} \\
\frac{0}{0} \\
\frac{0}{0} \\
\frac{0}{1}\end{array}$ & 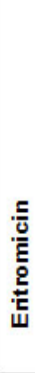 & 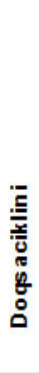 & 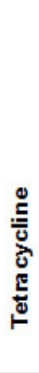 & 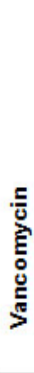 & 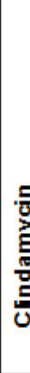 & 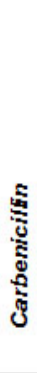 & 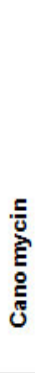 & $\begin{array}{l}\text { 동 } \\
\text { N } \\
\text { N }\end{array}$ & & & $\frac{\bar{\sigma}}{\frac{\mathbf{N}}{2}}$ & 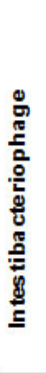 & 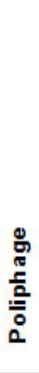 \\
\hline $\begin{array}{l}2 \\
3\end{array}$ & Heart & $\bar{F}_{-}$ & $\alpha$ & $R$ & $R$ & $\mathrm{R}$ & $\mathrm{R}$ & $R$ & $R$ & $R$ & 2 & t & & $3+$ & $3+$ & $3+$ \\
\hline 4 & Liver & $\begin{array}{l}\text { Shigell } \\
\text { a }\end{array}$ & $\beta$ & $\mathrm{R}$ & $2+$ & $3+$ & $4+$ & $R$ & $\mathrm{R}$ & $\mathrm{R}$ & $3+$ & & & $3+$ & $4+$ & $2+$ \\
\hline 5 & Liner & - & & $\mathrm{R}$ & $\mathrm{R}$ & $\mathrm{R}$ & $\mathrm{R}$ & R & $R$ & $R$ & R & & & $\mathrm{R}$ & $R$ & $R$ \\
\hline 6 & Rectum & E-coli & $\alpha$ & $\mathrm{R}$ & $\mathrm{R}$ & $\mathrm{R}$ & $\mathrm{R}$ & R & $R$ & $\mathrm{R}$ & R & & & $R$ & $\mathrm{R}$ & R \\
\hline 7 & $\sigma_{-\alpha}^{\alpha}$ & & & $\mathrm{R}$ & $\mathrm{R}$ & $\mathrm{R}$ & $\mathrm{R}$ & $R$ & $\mathrm{R}$ & $\mathrm{R}$ & $\mathrm{R}$ & & & R & R & R \\
\hline 8 & $\alpha$ & * & & $\mathrm{R}$ & $\mathrm{R}$ & $\mathrm{R}$ & $\mathrm{R}$ & $R$ & $\mathrm{R}$ & $\mathrm{R}$ & R & & & $R$ & $\mathrm{R}$ & R \\
\hline 9 & ${ }^{\alpha}{ }^{\alpha}$ & a & & $R$ & $\mathrm{R}$ & $\mathrm{R}$ & $\mathrm{R}$ & \begin{tabular}{|l}
$R$ \\
$R$
\end{tabular} & $\mathrm{R}$ & $\mathrm{R}$ & R & & & $R$ & $R$ & $\mathrm{R}$ \\
\hline 10 & $={ }^{\alpha}$ & a & & $\mathrm{R}$ & $\mathrm{R}$ & $R$ & $\mathrm{R}$ & $R$ & $\mathrm{R}$ & $\mathrm{R}$ & $R$ & & & $R$ & $\mathrm{R}$ & $R$ \\
\hline 11 & $\begin{array}{l}\text { Ready- } \\
\text { made food } \\
\# 1\end{array}$ & $\begin{array}{l}\text { candid } \\
\text { a }\end{array}$ & & & & & & & & & & & & & & \\
\hline 12 & $\begin{array}{l}\text { Ready- } \\
\text { made food } \\
\# 2\end{array}$ & $\begin{array}{l}\text { candid } \\
\text { a }\end{array}$ & & & & & & & & & & & & & & \\
\hline
\end{tabular}

Pathological bodies and ready-made food.

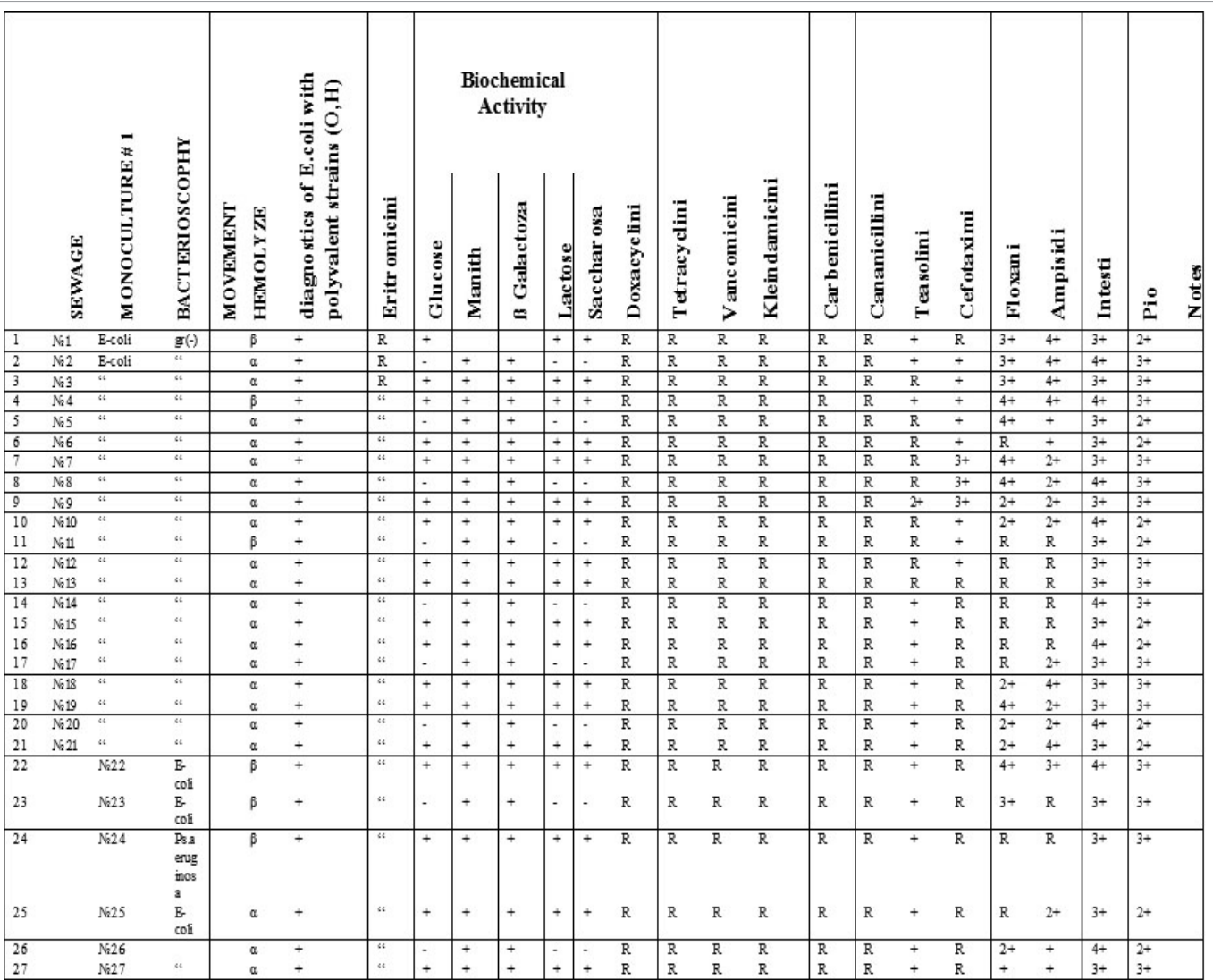

Bacteriological research on sensitivity on antibiotics, and phage sensitivity among 1-10 days old chickens. 


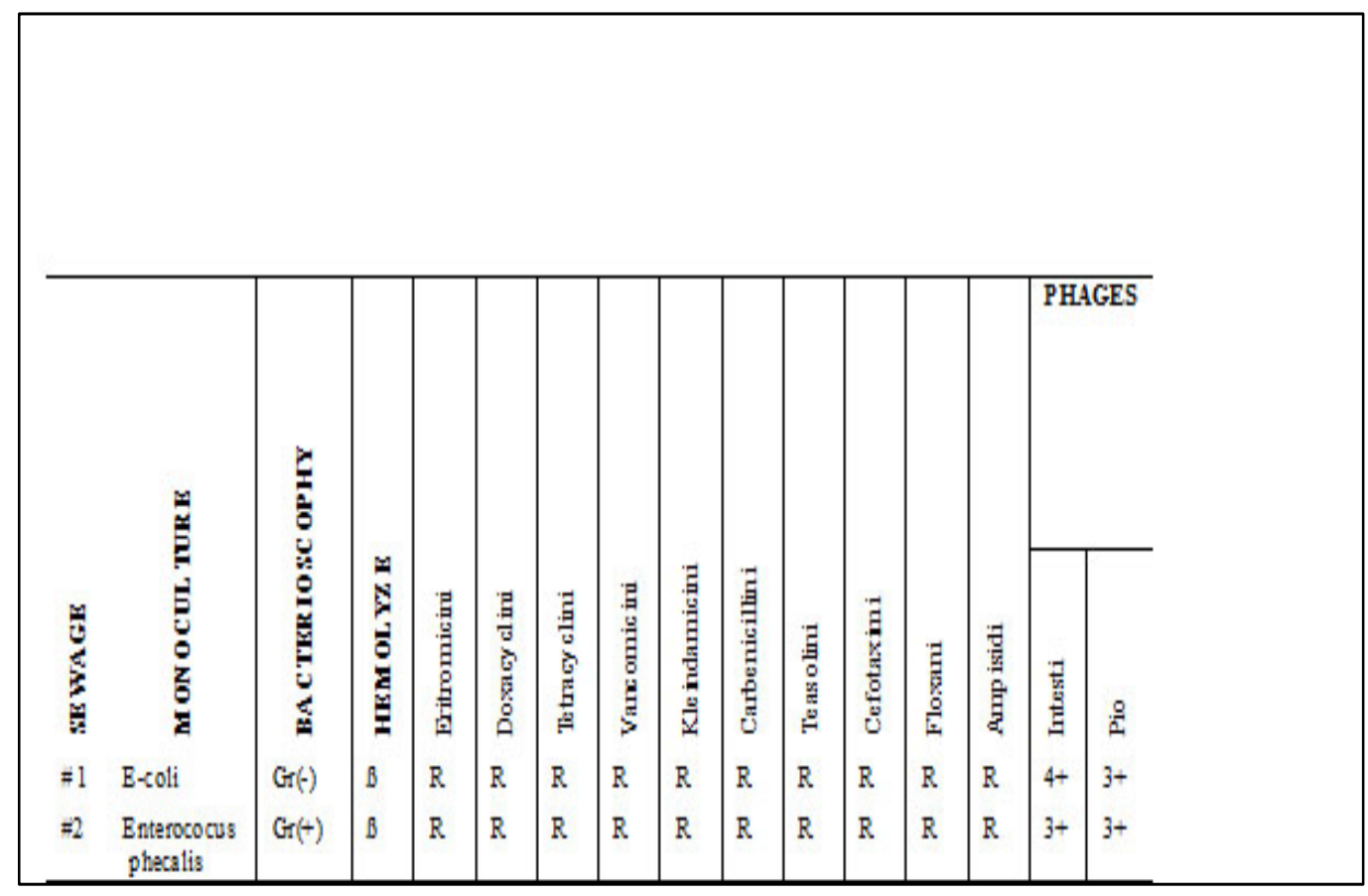

Bacteriophage research of sewage water in Krtsanisi poultry farm.

they may become sources of international bacterial pollution.

Kolkheti National Park unites wetlands and lake Paliastomidesignated Ramsar site. The lake Paliastomi is an important habitat for migratory waterfowl 194 different bird species are found in the national park, including 21 species that use the area during seasonal migration.

The lake Paliastomi may be considered as important source of bacterial pollution. Current local and international experience may enable us to use bacteriophages, as tracers for determination of bacterial pollution in water reservoirs as well as for bacterial clean up, as well [10].

Current technologies enable to apply to: visualization of bacterial pollution in water reservoirs through various modelling tools, for loading various types of data, including bacterial pollutants showing the time "playback" feature describing What, When, Where has been happening and what is the concentration size.

Therefore, will be required to make: review of existing sanitarybiological research of flowing waters; definition of dynamics of background sanitary-microbial indicators; study of biological characteristics of secreted pathogenic agents; study the spreading and die off pathogen organisms in relation to physical-chemical factors like light, salinity, temperature, sedimentation rates etc.

\section{Conclusion}

Management of bacterial pollution of water bodies of international importance need to meet the requirements of international, regional and national requirements. EU-Georgia Association Agreement sets out requirements on integrated approach for the management of water bodies.

Should be required to work out:

- Hydrodynamic model of lake Paliastomi:
- Hydrodynamic data including depths of water;

- Level of water;

- Inflowing waters;

- Wind velocity data;

- Bacteriological model (die off bacteria and phage distribution)

- Will be created modernized technology on drinking and bathing water bacterial monitoring, pollution prevention, mitigation and respond.

- Will be developed electronic visualization model for the development of different scenarios to make overview of dynamics of bacterial pathogens distribution in the water body and their possible clean up by environmentally applicable technology.

As a main project outcome intestibacteriophage is recommended in treatment of birds against esherichiosis staphylococci, protesus etc.

Intestibacteriophage is based on lysis properties of birds' staphylococcus, proteus and other bacteria. Preparation is given to chicken with water and food, as a preventive drug. Before giving water, as a preventive measure (106) of intestibacteriophage is mixed in 10 millilitre drinking water. As for treatment purposes 2 millilitres in 10 millilitre of water is given to birds.

For the preventive measures preparation, which is used with food is mixed 1mililiter-of preparation is mixed in 1 millilitre water and spray on 20-gram food. As for treatment measures 1 millilitre of intestibteriophage is mixed in 10 millilitre food. For the equal distribution of preparation in food, the food is thoroughly stirred and feeds the birds. The preparation is given to chicken once a day in the morning. Preventive course is $4-5$ days. Treatment course is 7-8 days.

Average -preventive daily dose for 0-60-day age chicken is $2 \mathrm{X} 106$ 
Citation: Abramia G, Golijashvili A, Rigvava S, Natidze M, Japarashvili N, et al. (2016) Bacteriophages against Antibiotic Resistant Salmonella Bacteria for the Possible Prevention and Treatment of Birds and Clean Up of their Water Habitats. J Vet Sci Technol 7: 395. doi: 10.4172/21577579.1000395

for 180 day old 4 X106 and higher than 180 days 8 X106. However, in case of epidemic over brake the use of antibiotics is not prohibits.

The authors thank the WB Georgian Agriculture Development Program's Project - CGS 03-70, "Veterinary Department of Georgia, Department of Veterinary, Georgian Agrarian University (former Zoo Veterinary Institute of Georgia), Ministry of Agriculture, Ltd. Biochimfarm and International Center for Environmental Research for the support of project implementation process and development of information materials that became basis for our publication.

None of the authors of this paper has a financial or personal relationship with people or organizations that could inappropriately influence or bias the content of the paper.

\section{References}

1. Friend M, Franson JC (2001) Salmonellosis. In: Field manual of wildlife diseases: general field procedures and diseases of birds. Ciganovich EA (ed) US Department of the Interior and U.S. Geological Survey, Washington, DC pp: 99-110.
2. Bacteriophages (1923-2004) Historical Survey.

3. World Health Organization.

4. Salmonella and Campylobacter in chicken meat-Nutrition and Consumer Protection Division Food and Agriculture Organization of the United Nations p: 18.

5. Krawiec M, Kuczkowski M, Kruszewicz AG, Wieliczko A (2015) Prevalence and genetic characteristics of Salmonella in free-living birds in Poland. BMC Vet Res 11: 15.

6. Demonstration and application of achievement of environmentally friendly and efficient technology on the use of treatment-preventive veterinary biopreparation of bacteriophages against antibiotic resistant salmonela infections in poultry.

7. Tizard I (2004) Salmonellosis in Wild Birds. Seminars in avian and exotic pet medicine 13: 50-66.

8. Hamer S, Lehrer E, Magle S (2012) Wild birds as sentinels for multiple zoonotic pathogens along an urban to rural gradient in greater Chicago, Illinois. Zoonoses and public health 59: 355-364.

9. Horton R, Wu G, Speed K, Kidd S, Davies R, et al. (2013) Wild birds carry similar Salmonella enterica serovar Typhimurium strains to those found in domestic animals and livestock. Res Vet Sci 95: 45-48.

10. Septemberi VG (2003) Provisional Instruction on the Use of Intestibacteriophages in Poultry. Head of Veterinary Department of the Ministry of Agriculture and Food. 